\title{
Dichlorvos exposure impedes extraction and amplification of DNA from insects in museum collections
}

\author{
Marianne Espeland ${ }^{1,2^{*}}$, Martin Irestedt ${ }^{3}$, Kjell Arne Johanson ${ }^{1}$, Monika Åkerlund ${ }^{4}$, Jan-Erik Bergh ${ }^{5}$, Mari Källersjö 3,6
}

\begin{abstract}
Background: The insecticides dichlorvos, paradichlorobenzene and naphthalene have been commonly used to eradicate pest insects from natural history collections. However, it is not known how these chemicals affect the DNA of the specimens in the collections. We thus tested the effect of dichlorvos, paradichlorobenzene and naphthalene on DNA of insects (Musca domestica) by extracting and amplifying DNA from specimens exposed to insecticides in two different concentrations over increasing time intervals.

Results: The results clearly show that dichlorvos impedes both extraction and amplification of mitochondrial and nuclear DNA after relatively short time, whereas paradichlorobenzene and naphthalene do not.

Conclusion: Collections treated with paradichlorobenzene and naphthalene, are better preserved concerning DNA, than those treated with dichlorvos. Non toxic pest control methods should, however, be preferred due to physical damage of specimens and putative health risks by chemicals.
\end{abstract}

\section{Background}

Natural history collections are an invaluable source of biological data [1-3]. These collections record the distribution of known taxa in space and time and document both what we know and what we don't know about the world's biota [4]. Biologists all over the world have been extracting ecological, morphological, phylogenetic, diversity and biogeographic data from museum specimens for decades, if not decennia [1]. More recently these specimens are also in frequent use for the extraction of DNA in e.g. molecular phylogenetic, population genetic and conservation genetic studies [5-9]. It could also be expected that Natural history collections will be much more important in molecular studies in the near future owing to; 1) difficulties to collect fresh biological material from many regions and the extinction of taxa due to habitat loss, and 2) the development of new highthroughput sequencing methods [10] and protocols that makes it possible to use these techniques for PCR-product sequencing [11] and conducting extensive

\footnotetext{
* Correspondence: marianne.espeland@nrm.se

'Swedish Museum of Natural History, Entomology Department, Box 50007,
} SE-104 05 Stockholm, Sweden molecular studies based on fragmented DNA in museum collections.

Museum collections are prone to attacks by insect pests, especially beetles of the family Dermestidae (Coleoptera). If left unattended these pests can completely destroy an insect collection within a few months time. Hence a variety of methods have been developed to eradicate the pest insects e.g. fumigation or other treatments with insecticides [12,13], traps [14-16], heating [17-19] or freezing of infested specimens [20-22] and modified atmosphere [23-28].

Many different insecticides have been used in eradication of pest insects in collections. The use is declining, but it is still utilized in many museums [29,30]. Several studies of the effects of insecticides on the pest insects e.g. $[12,31]$ and their effect on different materials in museum collections $[32,33]$ have been performed, but there are few studies of how insecticides affect the DNA of the specimens in natural history collections. Whitten et al [34] found no effect of sulphuryl fluoride (Vikane) on the DNA of herbarium specimens. According to Kigawa et al. [35] methyl bromide, ethylene oxide, propylene oxide and methyl iodide all affected the DNA in both freeze-dried mushrooms and chicken muscle

\section{() Biomed Central}


negatively, whereas sulphuryl fluoride did not. To our knowledge no studies on the effects of insect DNA have been performed.

Naphthalene, paradichlorobenzene and dichlorvos are some of the most frequently used insecticides in insect collections, but their effect on the DNA of insect specimens is not known. We therefore exposed dried insects to various concentrations of these insecticides over a period of 20 months (605 days), extracted DNA from the specimens and ran both total DNA extracts and polymerase chain reaction (PCR) products on agarose gels to investigate effects of these insecticides on the DNA of insect specimens.

\section{Methods}

Common houseflies (Musca domestica) were dried on silica gel for three weeks and then exposed to one of eight different treatments (Table 1). Insecticides were placed in $15 \mathrm{~cm}^{3}$ glass vials under a piece of cotton. Flies were placed on the cotton to avoid direct exposure to the insecticide. Vials where then sealed with plastic lids with silicone insulation to make them air tight and stored at room temperature. Recommended dosage and $10 \times$ recommended dosage of insecticides were calculated based on information on the insecticide containers. Recommended dosage for naphthalene and paradichlorobenzene were $150 \mathrm{~g} / \mathrm{m}^{3}$ air and $1.6 \mathrm{~g} / \mathrm{m}^{3}$ for dichlorvos. We used $15 \mathrm{~cm}^{3}$ vials in the experiments so these amounts transferred to $0.002 \mathrm{~g} / \mathrm{vial}$ for naphthalene and paradichlorbenzene and $2.4^{*} 10^{-4} \mathrm{~g} / \mathrm{vial}$ for dichlorvos. We did not have accurate enough equipment to measure as small amounts as the latter thus we used $0.001 \mathrm{~g} /$ vial which corresponds to roughly $41 \times$ the recommended dosage of dichlorvos. This might seem like a very high quantity, but it is justified since much higher doses of dichlorvos are used in real collections. A standard insect drawer in use at the Swedish Museum of Natural History has a volume of $6800 \mathrm{~cm}^{3}$ (6.8 1). This means that recommended dosage of one drawer should be $1 \mathrm{~g}$ for naphthalene and dichlorvos and as little as $0.01 \mathrm{~g}$ for dichlorvos. Considerably higher doses have been used in drawers at the Swedish Museum of Natural History (Figure 1). The potency of dichlorvos makes it virtually impossible to dose it correctly.

In addition to recommended dosage we also included a treatment with $10 \times(833 \times$ for dichlorvos) recommended

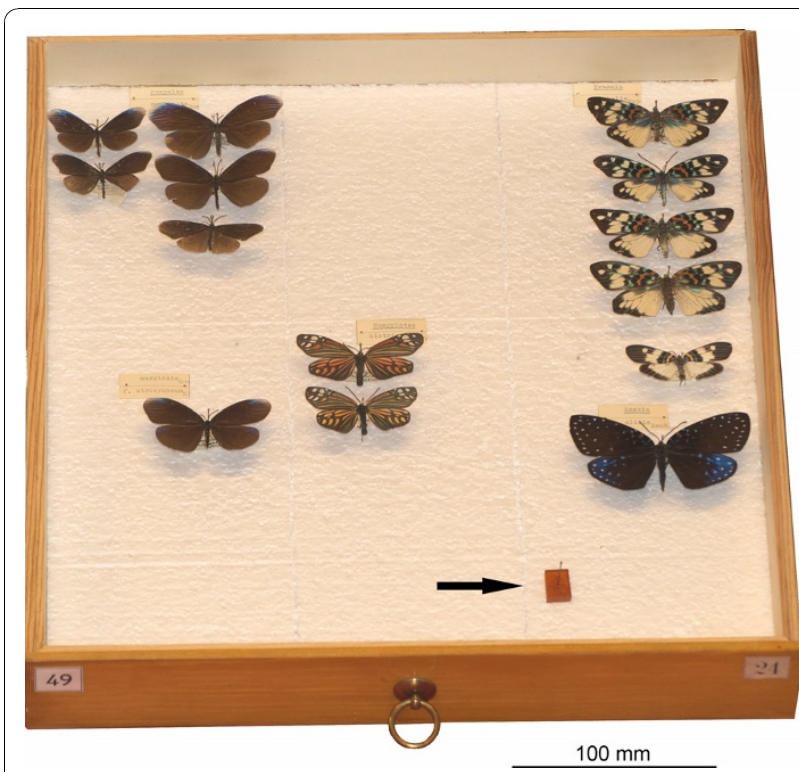

Figure 1 Dichlorvos (arrow) as used in insect drawers at the Swedish Museum of Natural History.

dosage $(0.02 \mathrm{~g} / \mathrm{vial})$ and controls without insecticides. Samples were taken with increasing intervals over a time period of 20 months (605 days) and DNA extracted according to the scheme in Table 2.

\section{Molecular procedures}

DNA was extracted from whole houseflies using the Qiagen DNeasy Tissue Extraction kit (Qiagen Inc., Valencia, California) which yields DNA fragments of length $50000 \mathrm{~kb}$ and shorter. Twelve $\mu \mathrm{l}$ of the aliquots were run directly on $1 \%$ agarose gels in $0.5 \times$ TBE buffer for 5 hours and visualized under UV light.

Fragments of comparable length of one mitochondrial (COI, 658 bp; primers LCO-HCO [36]) and one nuclear gene (EF1a, $716 \mathrm{bp}$; primers M46.1-R [37,38]) were amplified using Ready-To-Go ${ }^{\text {Tx }}$ PCR Beads (Amersham Pharmacia Biotech, Piscataway, New Jersey). Reaction mixtures consisting of $2 \mu \mathrm{l}$ template, $1 \mu \mathrm{l}$ primer (10

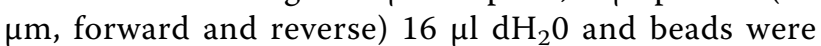
heated to $95^{\circ} \mathrm{C}$ for 5 minutes, followed by 40 cycles of 30 seconds at $95^{\circ} \mathrm{C}, 30$ seconds at a specific annealing temperature $\left(52^{\circ} \mathrm{C}\right.$ for $\mathrm{EF} 1 \mathrm{a}$ and to $50^{\circ} \mathrm{C}$ for $\left.\mathrm{COI}\right)$ and 50 seconds at $72^{\circ} \mathrm{C}$, and then a final extension of $8 \mathrm{~min}$ utes at $72^{\circ}$. PCR products were visualized by ultraviolet light on a $0.8 \%$ agarose gel after electrophoresis.

Table 1 The six insecticide treatments and controls in the current study.

\begin{tabular}{lllll}
\hline & I Dichlorvos & II Paradichlorbenzene & III Naphthalene & IV Control \\
\hline 1 High concentration & $0.02 \mathrm{~g} /$ vial & $0.02 \mathrm{~g} /$ vial & $0.02 \mathrm{~g} / \mathrm{vial}$ & $\mathrm{NA}$ \\
2 Low concentration & $0.001 \mathrm{~g} / \mathrm{vial}$ & $0.002 \mathrm{~g} / \mathrm{vial}$ & $0.002 \mathrm{~g} / \mathrm{vial}$ & $\mathrm{NA}$ \\
\hline
\end{tabular}


Table 2 Extraction dates and length of pesticide exposure (in days) for all samples.

\begin{tabular}{ccc}
\hline Sample & Extraction date & $\begin{array}{c}\text { Pesticide exposure } \\
\text { (days) }\end{array}$ \\
\hline 1 & $17 / 04 / 07$ & 1 \\
2 & $18.4-2007$ & 2 \\
3 & $19.4-2007$ & 3 \\
4 & $20.4-2007$ & 4 \\
5 & $22.4-2007$ & 6 \\
6 & $24.4-2007$ & 8 \\
7 & $26.4-2007$ & 10 \\
8 & $30.4-2007$ & 14 \\
9 & $8.5-2007$ & 22 \\
10 & $27.5-2007$ & 41 \\
11 & $11.7-2007$ & 86 \\
12 & $28.8-2007$ & 134 \\
13 & $14.10-2007$ & 181 \\
14 & $1.12-2007$ & 229 \\
15 & $18.1-2008$ & 278 \\
16 & $6.3-2008$ & 326 \\
17 & $23.4-2008$ & 374 \\
18 & $10.6-2008$ & 422 \\
19 & $10.12-2008$ & 605 \\
\hline
\end{tabular}

Samples shown on gels in this paper are given in bold.

If fragmentation is seen in both extraction and amplification then there is evidence that these insecticides cause degradation of DNA. If, on the other hand, initial gel runs on extracts exposed to insecticides are identical to controls, but amplification of genes are impossible or very difficult we have evidence that insecticides might inhibit amplification.

\section{Results}

Effect on total DNA

Visualization of DNA extracts on agarose gels showed that dichlorvos fragments DNA both in high and low concentration (Figure 2A-B). After four and twelve months of exposure of the high and recommended dosage dichlorvos respectively, the band of DNA of length around $23000 \mathrm{bp}$, which constitutes of most of the DNA in the control, has completely disappeared from the dichlorvos samples. Only a very low amount of highly degraded DNA ( $<500 \mathrm{bp})$ is present in these samples. No effect on DNA was seen in samples treated with naphthalene and paradichlorobenzene (Figure 3A, B, only high concentration, $0.02 \mathrm{~g} /$ vial, shown; control: Figure 3C).

\section{Amplification of nuclear and mitochondrial DNA}

After 134 days (sample 12, Figure 4A-I) of dichlorvos exposure (high concentration) amplification of EF1a is considerably impeded and after 229 days (sample 14, Figure 4A-I) it is no longer possible. Amplification of COI is impeded after 229 days (sample 14, Figure 5A-I) of dichlorvos exposure (high concentration). Very weak bands are, however, visible during the whole experiment (605 days) so amplification is possible, but made more difficult. When looking at the samples exposed to lower concentration of dichlorvos the results are less conclusive but amplification of both EF1a (Figure 4C-I) and COI (Figure $5 \mathrm{C}-\mathrm{I}$ ) is impeded by dichlorvos even here, indicated by weaker bands, especially for EF1a, for samples treated with dichlorvos than for the controls (Figures 4B-II, 4D-II). When compared with the controls (EF1a: Figure 4B-II, 4D-II; COI: Figure 5B-II, 5D-II), naphtalene (EF1a: Figures 4B-I, 4D-1; COI: Figures 5B-I, 5D-1) and paradichlorobenzene (EF1a: Figures 4A-II,
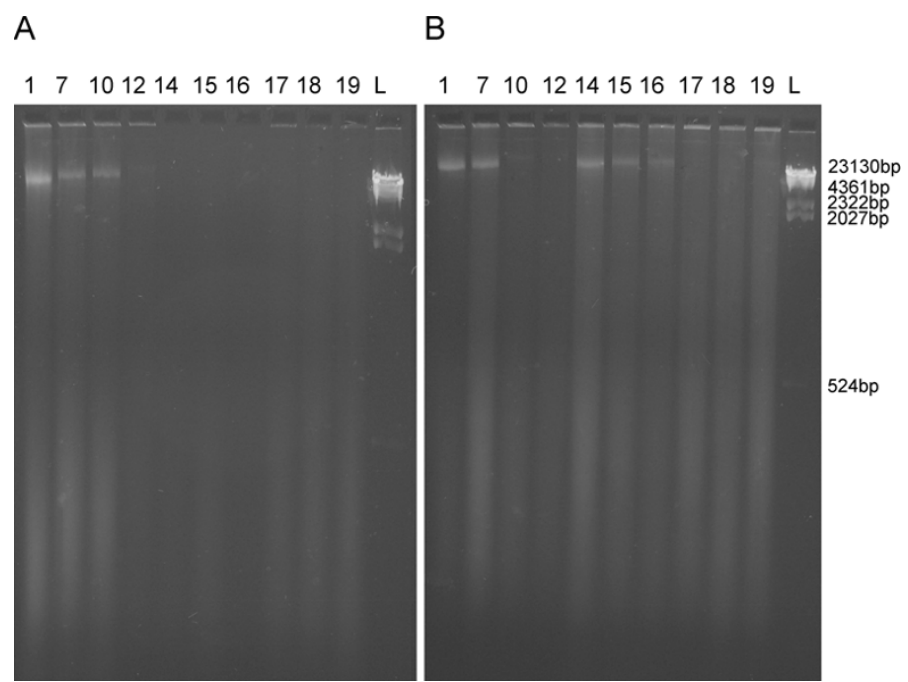

Figure 2 Total DNA extracts of dichlorvos exposed specimens. A) High concentration ( $0.02 \mathrm{~g} / \mathrm{vial})$. B) Low concentration (0.001 g/vial). L indicates ladder. See Table 2 for sample intervals. 

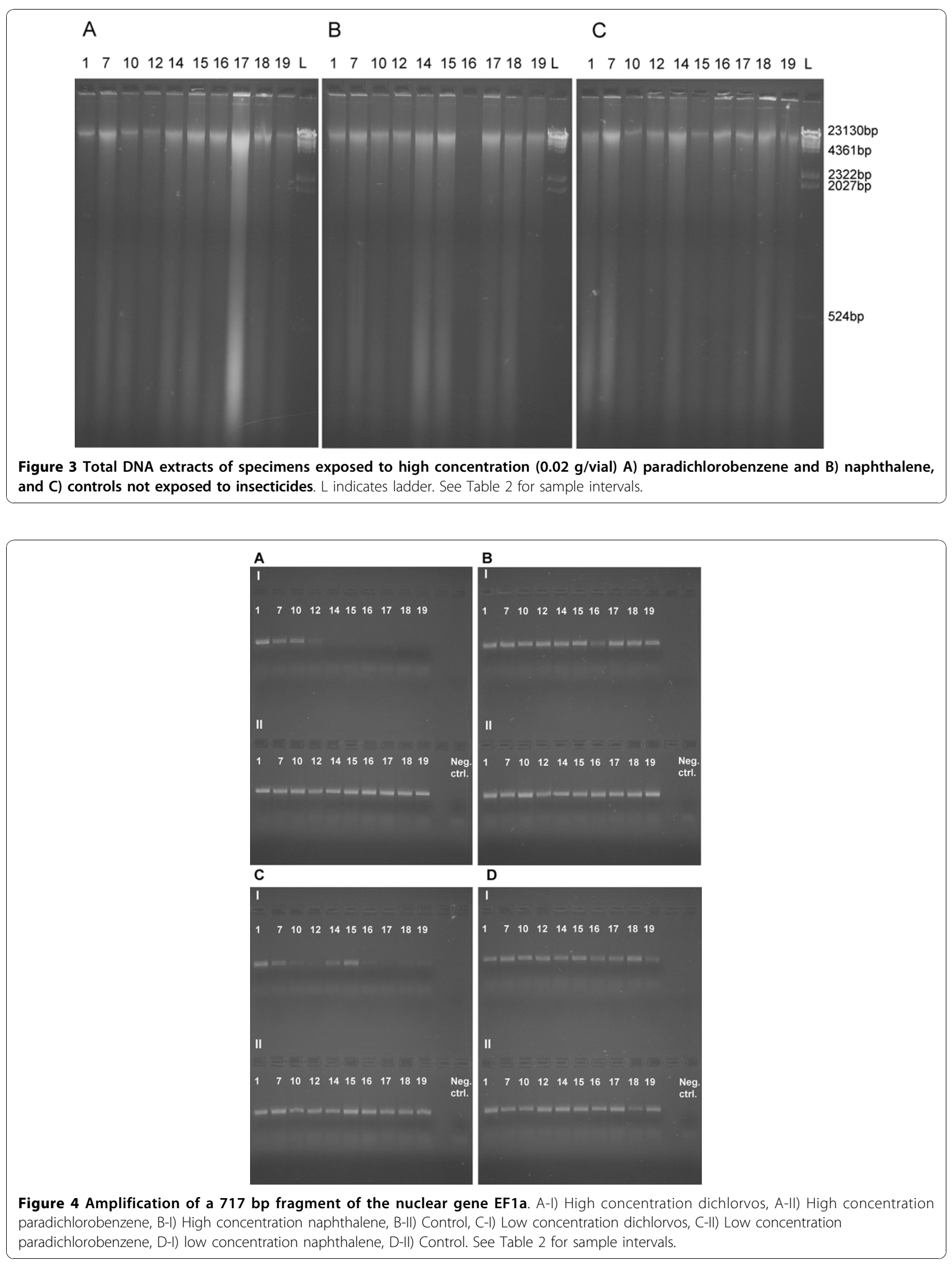


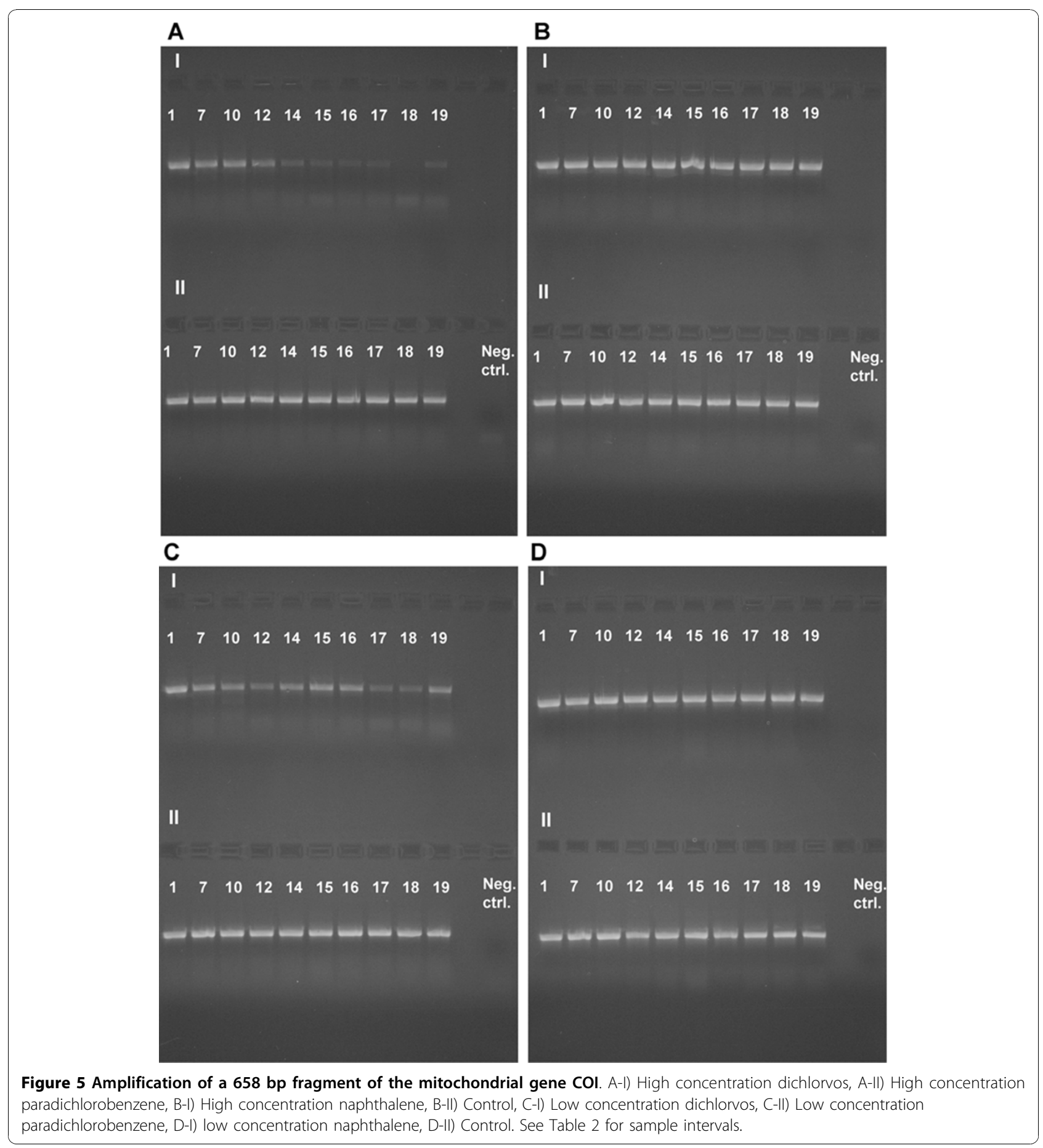

4C-II; COI: Figures 5A-II, 5C-II) do not seem to affect the amplification of neither EF1a nor COI.

\section{Discussion}

The use of DNA from organisms in museum collection is increasing and it is thus important to curate the collections with this in mind. Dichlorvos clearly affects the
DNA of insects negatively already after four months of exposure and the effect increases over time, whereas naphthalene and paradichlorobenzene do not seem to affect DNA, at least not over a time period of 20 months. Negative effects on DNA are observed both in total DNA extractions and amplification of nuclear and mitochondrial DNA, thus the major problem is 
fragmentation of DNA and not inhibition of PCR primers. Effects are also larger for the nuclear gene than for the mitochondrial gene, which is not unlikely since the mitochondrial gene is present as multiple copies in every cell, whereas nuclear DNA only in two copies. Mitochondria are also structurally strong which might lead to better preservation of mitochondrial DNA than its nuclear counterpart [39]. The concentration of insecticide used is also important with higher concentration resulting in increased damage of DNA. The dosages of dichlorvos used in this study might seem extremely high, but they (even the high dose) are probably closer to reality than the recommended dose. The pesticide is very potent even in small doses, and it is almost impossible not to use more than necessary. It is also possible that we will see similar results of DNA fragmentation for paradichlorobenzene and naphthalene when used in higher doses. Dichlorvos is a potent acetylcholinesterase inhibitor and can cause DNA damage in human cells at low concentrations, even after short exposure [40,41], and it is putatively carcinogenic in humans [42]. It has also been shown to cause severe damage on museum material, such as bleaching of colour, and even corrosion of metal [32,33]. Because of its deleterious effects to both human and insect DNA the use of dichlorvos for pest prevention in natural history collections should be strongly avoided. Even naphthalene and paradichlorbenzene, are suspected carcinogens [43,44]. They also effect colours and soften resins [45], and are documented less effective in killing the pests than dichlorvos [31]. Therefore they are not recommended for use in museums. Non-toxic methods such as freezing [21,22], or anoxic treatment [27] should be recommended if infestation has occurred since they are effective against pests and at the same time little hazardous to humans and items. On the other hand we wholeheartedly agree with Blyth \& Smith [46], that prevention is better than the cure.

\section{Conclusion}

The use of dichlorvos for pest eradication in natural history collections should be strongly avoided due to deleterious effects on DNA. Chemical eradication methods in general should be avoided since they can cause damage to specimens and are associated with putative health issues.

\section{Acknowledgements}

We are grateful to Keyvan Mirbakhsh, Mattias Myrenås, Pia Eldenäs and Bodi Cronholm at the Molecular Systematics laboratory (Swedish Museum of Natural History) for discussions about molecular lab procedures. Tobias Malm kindly helped with DNA extractions. We also thank Anticimex for providing the dichlorvos. The study was funded by the Swedish Museum of Natural History.

\section{Author details}

${ }^{1}$ Swedish Museum of Natural History, Entomology Department, Box 50007, SE-104 05 Stockholm, Sweden. ${ }^{2}$ Stockholm University, Zoological Institute, SE-106 09 Stockholm, Sweden. ${ }^{3}$ Swedish Museum of Natural History, Molecular Systematics Laboratory, Box 50007, SE-104 05 Stockholm, Sweden. ${ }^{4}$ Swedish Museum of Natural History, Research Department, PRE-MAL, Box 50007, SE-104 05, Stockholm, Sweden. ${ }^{5}$ Dalarna University College, SE-791 88 Falun, Sweden. ${ }^{6}$ Current address: Göteborg Botanical Garden, Carl Skottsbergs Gata 22 A, SE-413 19 Gothenburg, Sweden.

\section{Authors' contributions}

$M I, K J E, M \AA$, J-EB and MK conceived the project. ME set up the experiment, did the molecular work and wrote the paper. MI, ME and KJE discussed the molecular work. All authors discussed the experimental setup and read and approved the final manuscript.

\section{Competing interests}

The authors declare that they have no competing interests.

Received: 10 September 2009

Accepted: 18 January 2010 Published: 18 January 2010

\section{References}

1. Lane MA: Roles of natural history collections. Ann Mo Bot Gard 1996, 83:536-545.

2. Shaffer HB, Fisher RN, Davidson C: The role of natural history collections in documenting species declines. Trends Ecol Evol 1998, 13:27-30.

3. de L. Brooke M: Why museums matter. Trends Ecol Evol 2000, 15:136-137.

4. Ponder WF, Carter GA, Flemons P, Chapman RR: Evaluation of museum collection data for use in biodiversity assessment. Conserv Biol 2001, 15:648-657.

5. Roy MS, Girman DJ, Taylor AC, Wayne RK: The use of museum specimens to reconstruct the genetic variability and relationships of extinct populations. Experientia (Basel) 1994, 50:551-557.

6. Thomas RH: Analysis of DNA from natural history collections. EXS (Basel) 1994, 69:311-321.

7. Whitfield JB: Destructive sampling and information management in molecular systematic research: an entomological perspective. Managing the modern herbarium: An interdisciplinary approach Society for Preservation of Natural History Collections and Royal Ontario Museum, OttawaByers S, Metsger D 1999, 301-314.

8. Payne RB, Sorenson MD: Museum collections as sources of genetic data. Bonn Zool Beitr 2002, 51:97-104.

9. Wandeler P, Hoeck PEA, Keller LF: Back to the future: museum specimens in population genetics. Trends Ecol Evol 2007, 22:634-642.

10. Margulies M, Egholm M, Altman WE, Attiya S, Bader JS, et al: Genome sequencing in microfabricated high-density picolitre reactors. Nature 2005, 437:376-380.

11. Binladen J, Gilbert MTP, Bollback JP, Panitz F, Bendixen C, Nielsen R, Willerslev E: The use of coded PCR primers enables high-throughput sequencing of multiple homolog amplification products by 454 parallel sequencing. Plos One 2007, 2:e197

12. Williams SL, Walsh EA: Effect of DDVP on a museum insect pest. Curator 1989, 32:34-41

13. Jensen K-MV, Hansen SL: Evaluation of chemical methods for prevention of damages to textiles due to Dermestidae and Tineola bisselliella (Lepidoptera: Tineidae). Proceedings of the third Nordic Symposium on Insect Pest Control in Museums: September 24-25 1998; Stockholm, Sweden Åkerlund M 1998, 112-119.

14. Burkholder WE, Phillips JK: Trapping techniques for Dermestid and Anobiid beetles. A guide to museum pest control Washington D.C.: Foundation of the American Institute for Conservation of Historic and Artistic works and the Associations of Systematics CollectionsZycherman LA, Schrock JR 1988, 109-111.

15. Child RE, Pinniger DB: Insect trapping in museums and historic houses. Proceedings of the First International Conference on Urban Pests: 30 June - 3 July; Cambridge, England Wildey KB, Robinson WH 1993, 267-270.

16. Ackery PR, Pinniger DB, Chambers J: Enhanced pest capture rates using pheromone-baited sticky traps in museum stores. Stud Conserv 1999, 44:67-71. 
17. Strang TJK: Principles of heat disinfestation. Integrated pest management for collections, Proceedings of 2001: a Pest Odyssey Maney Publishing, LondonKingsley H, Pinniger D, Xavier-Rowe A, Winsor P 2001, 114-129.

18. Ackery PR, Testa JM, Ready PD, Doyle AM, Pinniger DB: Effects of high temperature pest eradication on DNA in entomological collections. Stud Conserv 2004, 49:35-40.

19. Ackery PR, Pinniger DB, Doyle A, Roux K: Heat treatment of entomological drawers using the thermo lignum heat process. Collection Forum 2005, 21:117-125.

20. Strang TJK: The Effect of Thermal Methods of Pest Control on Museum Collections. Preprints of the 3rd International Conference on Biodeterioration of Cultural Property: 4-7 July, 1995; Bangkok, Thailand 1996, 199-212.

21. Berry J: Battle of the beasts: treatments of a pest infestation in the mounted mammal collection at Liverpool Museum. Integrated pest management for collections, Proceedings of 2001: a Pest Odyssey Maney Publishing, LondonKingsley H, Pinninger D, Xavier-Rowe A, Winsor P 2001, 130-134.

22. Bergh J-E, Jensen $\mathrm{K}-\mathrm{M}$, Åkerlund $\mathrm{M}$, Hansen SL, Andrén M: A contribution to standards for freezing as a pest control method for museums. Collection Forum 2006, 21:117-125.

23. Gilberg M: Inert atmosphere fumigation of museum objects. Stud Conserv 1989, 34:80-84

24. Hanlon G, Daniel V, Ravenel N, Maekawa S: Dynamic system for nitrogen anoxia of large museum objects: A pest eradication case study. Pre-print of the 2nd International Conference on Biodeterioration of Cultural Property: 58 October 1992; Yokohama, Japan 1993, 387-396.

25. Rust JM, Kennedy JM, Daniel V, Druzik JR, Preusser FD: The feasibility of using modified atmospheres to control insect pests in museums. Restaurator 1996, 17:43-60.

26. Valentin N, Preusser F: Nitrogen for biodeterioration control on museum collections. The Third Pan-American Biodeterioration Society 1990, 3:511-523.

27. Valentin N: Comparative analysis of insect control by nitrogen, argon and carbon dioxide in museum, archive and herbarium Collections. Int Biodet Biodeg 1993, 32:263-278.

28. Valentin N, Bergh J-E, Ortega R, Åkerlund M, Hallström A, Jonsson K: Evaluation of a portable equipment for large scale de-infestation in museum collections using a low oxygen environment. Proceedings of the 13th Triennial Meeting of the ICOM-CC in Rio de Janeiro ICOM Committee for Conservation, LondonVontobel R 2002, 96-101.

29. Pinniger DB: Pest management in museums, archives and historic houses Archetype Publications Ltd., London 2001.

30. Pinniger DB, Winsor P: Integrated pest management. A guide for museums, libraries and archives Museums, Libraries and Archives Council, London 2004.

31. Linnie MJ, Keatinge MJ: Pest control in museums: toxicity of paradichlorobenzene, 'Vapona'TM, and naphthalene against all stages in the life-cycle of museum pests, Dermestes maculatus Degeer, and Anthrenus verbasci (L.) (Coleoptera: Dermestidae). Int Biodet Biodeg 2000, 45:1-13.

32. Stone JL, Edwards JA: Dichlorvos in museums: An investigation into its effect on various materials. A guide to museum pest control Foundation of the American Institute for Conservation of Historic and Artistic Works and the Associations of Systematics Collections, Washington D.CZycherman LA, Schrock JR 1988, 159-167.

33. Williams SL, Walsh EA: Effect of DDVP on a museum materials. Curator 1989, 32:49-69.

34. Whitten WM, Williams NH, Glover KV: Sulphuryl fluoride fluoride fumigation: effect on DNA extraction and amplification from herbarium specimens. Taxon 1999, 48:507-510.

35. Kigawa $R$, Nochide $H$, Kimura $H$, Miura D: Effects of various fumigants, thermal methods and carbon dioxide treatment on DNA extraction and amplification: A case study on freeze-dried mushroom and freeze-dried muscle specimens. Collection Forum 2003, 18:74-89.

36. Folmer OBM, Hoeh W, Lutz R, Vrijenhoek R: DNA primers for amplification of mitochondrial cytochrome $\mathrm{c}$ oxidase subunit I from diverse metazoan invertebrates. Mol Mar Biol Biotechnol 1994, 3:294-299.

37. Whiting MF: Mecoptera is paraphyletic: multiple genes and phylogeny of Mecoptera and Siphonaptera. Zool Scr 2002, 31:93-105.

38. Kjer KM, Blahnik RJ, Holzenthal RW: Phylogeny of Trichoptera (caddisflies): characterization of signal and noise within multiple datasets. Syst Biol 2001, 50:781-816.
39. Nielsen H, Engberg J, Thuesen I: DNA from artic human burials. Ancient DNA: Recovery and analysis of genetic material from palaeontological, archaeological, museum, medical and forensic specimens Springer Verlag, Berlin, GermanyHerrmann B, Hummel S 1994, 31-58.

40. Remington SE, Jowseya PA, Williams FM, Blaina PG: Investigations into the genotoxic potential of dichlorvos. Toxicology 2008, 253:13-14.

41. Atherton KM, Williams FM, Jameson S, Mutch E: DNA damage by dichlorvos and repair profiles in human lymphocytes, in vitro. Toxicology 2008, 226:53.

42. Maele-Fabry van G, Laurent C, Willems JL: Dichlorvos and carcinogenicity: A systematic approach to a regulatory decision. Regul Toxicol Pharmacol 2000, 31:13-21.

43. Barter JA, Sherman JH: An evaluation of the carcinogenic hazard of 1,4Dichlorobenzene based on internationally recognized criteria. Regul Toxicol Pharmacol 1999, 29:64-79.

44. Schreiner C: Genetic toxicity of naphthalene: A review. J Toxicol Environ Health Part B Crit Rev 2003, 6:161-183.

45. Dawson J: The effects on insecticides on museum artifacts and materials. A guide to museum pest control Washington D.C.: Foundation of the American Institute for Conservation of Historic and Artistic works and the Associations of Systematics CollectionsZycherman LA, Schrock JR 1988, 135150.

46. Blyth V, Smith S: Prevention is better than the cure. Victoria Albert Conserv J 2005, 50:26-27.

\section{doi:10.1186/1742-9994-7-2}

Cite this article as: Espeland et al:: Dichlorvos exposure impedes extraction and amplification of DNA from insects in museum collections. Frontiers in Zoology 2010 7:2.

\section{Submit your next manuscript to BioMed Central and take full advantage of:}

- Convenient online submission

- Thorough peer review

- No space constraints or color figure charges

- Immediate publication on acceptance

- Inclusion in PubMed, CAS, Scopus and Google Scholar

- Research which is freely available for redistribution

Submit your manuscript at www.biomedcentral.com/submit
Biolied Central 